\title{
SUBCONTRATAÇÃO E INFORMALIDADE NA CONSTRUÇÃO CIVIL, NO BRASIL E NA FRANÇA
}

\author{
Luciano Rodrigues Costa"
}

\begin{abstract}
Este artigo apresenta uma análise comparativa do mercado de trabalho do setor da Construção Civil, no Brasil e na França, em um contexto de flexibilização. Fruto de pesquisas de campo em canteiros de obras, nesses dois países, o texto aborda especificidades da informalidade dos contratos de trabalho no setor, que vêm produzindo uma transferência das ilegalidades das grandes para as pequenas empresas. No caso Francês, mediante as agências de temporários. No Brasil, através das pequenas empresas clandestinas, denominadas "gatas". Enfatizam-se a percepção dos trabalhadores frente às ilegalidades e suas estratégias para se manter no mercado. No caso Francês, ressalta-se o trabalho de imigrantes clandestinos ou portadores de títulos de estadia precários, viabilizados pelas agências de temporários. No Brasil, percebe-se que o setor sempre se organizou com base na informalidade e busca, aos poucos, fidelizar os trabalhadores, ainda que se mantenha predominante o trabalho informal.

PALAVRAS-CHAVE: informalidade, subcontratação, construção civil, trabalho, precariedade.
\end{abstract}

O trabalho, na construção civil, sempre foi marcado por duas características, que, durante muito tempo, foram interpretadas como idiossincráticas: a informalidade dos contratos de trabalho e a instabilidade destes postos. A informalidade diz respeito ao uso de elevado contingente de trabalhadores independentes e de assalariados não-registrados. A alta instabilidade no setor, por sua vez, se traduz num regime particular de emprego, caracterizado, sobretudo, por sua elevada rotatividade. O caráter descontínuo do processo produtivo, no qual predomina o princípio da sucessão (em que há etapas somadas para dar origem a um produto final, e não a simultaneidade das atividades, como ocorre em vários setores industriais), sempre acentuou a mobilidade da força de trabalho, dando-lhe uma característica específica. Essa alta rotatividade é favorecida não só pela demanda por diferentes especialidades, em cada etapa da

* Doutor em Ciências Sociais, com estágio sanduíche na Université de Toulouse le Mirail. Professor substituto na UFV (Universidade Federal de Viçosa).

Av. P.H Rolfs s/n, Campus Universitário. Cep: 36570-000 Vicosa, Minas Gerais - Brasil. Irodrigues00@yahoo.com.br obra, mas, também, pelo caráter extremamente cíclico da atividade. Essas especificidades do trabalho na construção civil fazem com que a figura do "peão" seja o seu personagem principal. $\mathrm{O}$ termo, comumente atribuído aos trabalhadores do setor, significa, justamente, aquele que roda, e não tem estabilidade (Morice, 1992). Não é por acaso que a construção civil sempre foi uma "porta de entrada" para imigrantes e para migrantes de origem camponesa, sem "qualificação" profissional reconhecida. Indivíduos oriundos de migrações definitivas, temporárias ou, ainda, derivadas da alternância entre atividades rurais e urbanas, sempre encontraram, na construção civil, o primeiro emprego, sobretudo, devido à simplicidade de algumas de suas tarefas. O predomínio de trabalhadores com menor qualificação formal e com baixos salários demonstra a vulnerabilidade a que estão submetidos.

Esse perfil da força de trabalho nessa atividade, entretanto, não é recente. $\mathrm{O}$ setor, com efeito, funciona, há muitas décadas, com formas precárias de trabalho. Com relação à realidade brasileira especificamente, pode-se pensar que 
oferece um perfil acentuado de algumas das condições de seu mercado de trabalho. As formas tradicionais de contratação da construção civil, antigamente vistas como diferenciadas e particulares, estenderam-se para outros setores, constituindo-se, atualmente, não mais formas atípicas, mas a forma predominante em várias atividades. As contratações atuais têm sido, muitas vezes, realizadas através da flexibilização dos contratos, das redes de subcontratação, da compressão salarial e da ausência dos direitos trabalhistas, entre outras formas que caracterizam as transformações no mercado de trabalho contemporâneo. As novas formas de contratação se constituem com base na flexibilidade e na precarização salarial e, com elas, produz-se uma obliteração das fronteiras entre a formalidade e a informalidade, em um cenário no qual a precarização do trabalho se dá, também, no âmbito das modalidades contratuais legais, e não somente no meio do trabalho não-registrado.

Essa precarização, no entanto, não se constitui como uma novidade no setor, já que ele sempre praticou formas ilegais de contratação, com as quais as fronteiras entre o formal e o informal se revelam fluidas. A construção civil oferece um campo privilegiado de observação da realidade atual, justamente pelo caráter híbrido do seu mercado de trabalho, expresso em diversos momentos do processo produtivo e sob diferentes arranjos. Uma primeira modalidade de articulação se caracteriza pela alternância entre o trabalho formal, realizado nas empresas, e os pequenos trabalhos informais, de curta duração e em pequena escala, denominados de "biscates". A descontinuidade do processo produtivo, determinada pelos ciclos de atividade próprios do setor, além disso, torna comum a demissão em massa, ao fim de cada empreendimento, a qual se faz acompanhar, sempre, das promessas de reinserção, em uma nova obra. Entre a finalização de uma obra e o início de outra, os trabalhadores alternam períodos de ocupação e de desocupação, o que torna a incerteza na ocupação uma rotina. A informalidade também se conjuga à formalidade, dentro dos canteiros de obras, quando os trabalhadores, muitas vezes vinculados formalmente, dispõemse a realizar tarefas pagas por produtividade, fora dos horários normais de serviço, como uma alternativa de ampliação de seus rendimentos. Contribui para isso o fato de muitos profissionais, sobretudo, migrantes, morarem no próprio canteiro da obra. Nesse caso, o espaço de trabalho envolve suas vidas diárias, de modo que trabalhar nos horários e inclusive nos dias de descanso passa a ser uma opção de aumento de ganho mensal.

Uma segunda modalidade, que revela o caráter híbrido do setor, diz respeito à redução do prazo de execução das obras, cada vez mais curto, o que faz com que as empresas se utilizem largamente dos contratos por produtividade, nos quais, normalmente, o registro do trabalhador é uma forma de mascarar as ilegalidades cometidas em relação à não-atribuição dos direitos trabalhistas. Transferem-se para o trabalhador todos os encargos previdenciários, além da responsabilidade de "construir o seu salário".

A construção civil, contudo, deve ser entendida dentro de um contexto mais amplo de mudanças ocorridas no mundo do trabalho, sobretudo, nas últimas décadas. O fato é que a informalidade tem se consolidado como um importante mecanismo de regulação do mercado de trabalho, no qual o crescimento do desemprego e das atividades não-institucionalizadas se revela uma constante, também nos países considerados de Primeiro Mundo, onde as imigrações internacionais vêm impondo desafios aos Estados Nacionais. O alcance universal de alguns desses fenômenos oferece uma possibilidade de se conectar, conceitualmente, as análises do mercado de trabalho brasileiro, ou mesmo da América Latina, à análise do que acontece nos países industrializados. As reflexões de Portes e Castells (1989) e Sassen (1989) demonstram que o fenômeno da informalidade não é uma característica exclusiva dos países em desenvolvimento, nem de setores excluídos de uma economia industri- 
alizada, mas uma contingência da vida econômica contemporânea. Ou seja: "a economia informal não é uma eufemismo para a pobreza, mas sim uma forma específica de relação de produção, já a pobreza é um tributo da distribuição." (Portes; Castells; Benton, 1989, p.22). A informalidade, interpretada por organismos como a OIT, nos anos 1970, como um desajuste da industrialização, que poderia ser superada a partir do desenvolvimento dos países, passa a ser entendida, mais recentemente, como uma estratégia de gestão do trabalho, centrada na subcontratação e na precarização dos contratos. Assim, a análise da velha noção de informalidade, de uma dimensão comparativa, torna-se útil para o entendimento das mudanças no mercado de trabalho contemporâneo. Se, nos anos 1960 e 1970, imaginava-se o desenvolvimento de países como o Brasil através da ampliação do trabalho assalariado, e, portanto, da redução da informalidade, a partir de 1990, o que se verificou foi uma difusão de novas formas contratuais nos países industrializados, nos quais a informalidade atual das relações de trabalho, nesses países, apresenta contornos próximos à dos países latino-americanos.

Nos países desenvolvidos, os fluxos migratórios vêm impondo intensos debates em torno da interdependência crescente, no quadro da mundialização, entre a economia informal e a formal. $\mathrm{O}$ endurecimento das medidas repressivas dos Estados nacionais, frente à entrada de imigrantes, através dos instrumentos de cooperação entre os países, que permitem a expulsão coletiva de imigrantes "indocumentados", contrapõe-se à porosidade das fronteiras. Em relação a migrantes com vínculo de trabalho (Carnet, 2008), percebe-se certa tolerância, que, entretanto, não está ligada a argumentos humanistas ou à solidariedade. De todo modo, se a economia informal, por um lado, se apresenta como indispensável à dinâmica econômica, por outro, intensifica-se o controle sobre as fronteiras (Peralva, 2007). O aparente paradoxo, produzido pela ambivalência das instituições estatais das economias receptoras de imigrantes, explica-se, justamente, pela interdependência entre a formalidade e a informalidade das relações de trabalho. Nesse contexto, a política de tolerância da imigração irregular se torna "a condição sine qua non do desenvolvimento da função econômica dessa imigração: fazer dos novos imigrantes os novos explorados do capitalismo mundializado, longe das proteções e das garantias que oferecem as legislações do trabalho" (REA, 2005, p.6). A manutenção de trabalhadores em situações ilegais parece responder às exigências econômicas de alguns setores, como é o caso da construção civil, em que se percebe uma convergência entre a ilegalidade das estadias dos imigrantes e os tipos de fraudes existentes nas formas dos contratos de trabalho.

A precariedade do trabalho, na construção civil não é um fato recente, não apenas nas chamadas regiões em desenvolvimento, como também em países mais desenvolvidos, como a França. Mesmo nos chamados Trinta Anos Gloriosos, quando as indústrias europeias (a automobilística, por exemplo) procuraram estabilizar sua mão de obra, a construção civil não se mostrou, efetivamente, preocupada em amparar legalmente seus trabalhadores. As características da atividade, como se demonstrou acima, tornam uma necessidade a alta flexibilidade em relação ao trabalho, a qual, conjugando-se às flutuações conjunturais, faz do recurso a uma mão de obra pouco qualificada e pouco remunerada a principal alternativa, mesmo que isso produza a desregulamentação das condições salariais e das proteções sociais. No caso francês, um aspecto se destaca. Trata-se do crescimento significativo da utilização do trabalho temporário por parte das construtoras, agenciado por empresas especializadas nesses tipos de contrato, os quais apresentaram um aumento considerável no setor, desde a sua legalização em 1972.

Quanto ao Brasil, migrações internas sempre forneceram mão de obra necessária à construção civil, sobretudo para os principais centros econômicos do país. O setor representa, para os migrantes jovens, de origem rural e baixa es- 
colaridade, vindos de regiões mais pobres do país, a oportunidade do primeiro emprego, de inserção em setores urbanos e de ascensão social. As portas dos canteiros de obras sempre estiveram abertas a esses jovens. Para os empresários do setor, eles significam uma mão de obra de baixo custo, habituada às dificuldades do trabalho pesado do campo e, ainda, motivada para enfrentar as adversidades da nova localidade e dos canteiros de obras. Os jovens migrantes, além disso, possuem certa experiência em relação aos trabalhos e às ferramentas utilizadas na construção, com as quais se familiarizam muito cedo nos serviços rurais. Atualmente, parece que o recrutamento dos trabalhadores se concentra mais nas periferias das grandes cidades do que na dependência de migrações (Tomasi, 1999). Como demonstra Cockell (2008) para o caso de São Carlos, em São Paulo, a construção parece absorver um novo perfil de trabalhador, o dos profissionais qualificados que se tornaram obsoletos e foram descartados de vários segmentos do mercado de trabalho. Em que pese esses novos elementos, os migrantes representam, ainda, um grande contingente de trabalhadores nos canteiros de obra brasileiros, nos quais se observam fortes ligações com modelos culturais e modos de vida típicos da cultura camponesa e artesanal. Devido à dependência de uma mão de obra flexível em algumas ocupações pouco qualificadas, a construção continua sendo uma opção, sobretudo para as empresas de pequeno porte.

Naturalmente, a especificidade da produção no setor precisa ser levada em conta, quando se investiga quaisquer aspectos relacionados às suas atividades. A grande variabilidade, a flexibilidade e, sobretudo, a descontinuidade do processo produtivo produzem uma elevada instabilidade, bastante característica. A especificidade se revela em inúmeras condições (sociais, econômicas, culturais, técnicas, estéticas etc.), definindo a construção por um modo próprio de ser e de fazer, diferente daquele de outros setores industriais. Mesmo reconhecendo que cada setor produtivo possui especificidades, as características intrínsecas da construção civil tornam-se fundamentais para se entenderem as características das relações de trabalho, pois é o contexto da descontinuidade e de grande variabilidade das atividades que induze a um elevado índice de informalidade e a formas precárias dos contratos de trabalho, a alta rotatividade e as subcontratações, conformando também uma realidade vivenciada pelos países desenvolvidos. Se a natureza das tarefas aproxima o setor do artesanato, por outro, o uso do planejamento e de concepções técnico-científicas na organização do trabalho na construção civil a aproxima dos setores industriais. As características do processo produtivo da construção dependem dos saberes de ofício, nos quais a autonomia dos trabalhadores se revela como um elemento fundamental para o desenvolvimento das tarefas. Isso levou o setor a "resistir", mesmo com as várias tentativas de implementação, ao longo do século XX, das práticas tayloristas de gestão do trabalho. Portanto, as especificidades dessa atividade fizeram com que se instituísse um tipo de gestão muito particular, envolvida por relações pessoais, paternalistas, muitas vezes autoritárias, em um jogo de relações de confiança que têm como figura emblemática o mestre de obras.

Este artigo analisa o mercado de trabalho do setor da construção civil na França e no Brasil, com base em pesquisas etnográficas realizadas em canteiros de obras, em ambos os países, destacando dois temas principais. O primeiro diz respeito ao trabalho dos imigrantes e suas formas de contratação, com ênfase nas agências de temporários francesas. O segundo tem como foco a informalidade dos contratos de trabalho e a transferência das ilegalidades para outras empresas - na França, para as agências de temporários, e, no Brasil, para as empresas denominadas "gatas". Sobre esse último aspecto, no caso brasileiro, são analisados os dados sobre formas de contratos clandestinos de trabalho, bem como a percepção dos trabalhadores sobre tais ilegalidades. Na França, o trabalho de campo ocorreu na cidade de Toulouse, com duração de quatro me- 
ses. No canteiro de obras pesquisado, quando da minha chegada, havia quarenta pessoas trabalhando, sendo somente quatro franceses, que assumiam cargos de chefia, e o restante constituído de imigrantes. No Brasil, a pesquisa se realizou na Região Metropolitana de Belo Horizonte (RMBH), durante seis meses. No canteiro pesquisado no Brasil, eram vinte e três pessoas trabalhando, doze com contratos informais e onze com formais, ou seja, nesse último caso, com carteira assinada.

\section{O trabalho temporário na construção francesa}

O trabalho temporário na França tornouse a forma mais conhecida de intermediação de mão de obra nos canteiros, sendo predominante em alguns ofícios. As mudanças na legislação do trabalho ocorridas na década de 1970, na França, quando, de fato, generalizou-se essa forma de contrato, ajudam a compreender a evolução do trabalho temporário nesse país. Naquele momento, observavam-se algumas tendências antagônicas: as dificuldades do processo de demissão, devido à legislação trabalhista, acabou por facilitar o uso do trabalho temporário. Uma lei de julho de 1973 dava mais garantias aos trabalhadores, condicionando as demissões a justificativas "reais e sérias", ou seja, estabelecia que, obrigatoriamente, deveriam dizer respeito ao comportamento dos trabalhadores ou estar ligadas a uma situação econômica delicada, vivenciada pela empresa (Jounin, 2008), o que dificultava as demissões. O setor da construção civil praticava, largamente, demissões ao fim de cada obra, e foi diretamente atingido por essa mudança na legislação. Desde então, passou a ser sua pauta de reivindicação, por meio das entidades de classe, um tipo de contrato específico, que atendesse às suas necessidades, ou seja, que permitisse demitir, livremente, ao fim de cada empreendimento. Uma lei anterior - de janeiro de 1973 - já instituía a proibição da intermediação da mão de obra com fins lucrati- vos, o que deixou o setor da construção em situação delicada, uma vez que fazia uso dessa prática, denominada marchandage. Se essas duas leis objetivaram a estabilização dos contratos, outras, elaboradas na mesma década, acabaram por causar efeitos inversos. Um exemplo é uma lei de dezembro de 1975, que legalizou a subcontratação. Antes disso, em janeiro de 1972, um ano antes da proibição da intermediação da mão de obra, regulamentaram-se as agências de trabalho temporário, as chamadas travail temporaire, posteriormente denominadas intérim, as quais centralizavam esses contratos. A legislação específica reclamada pelo setor - a de um único contrato para cada canteiro - só foi efetivada muito tardiamente, em 1978, quando o próprio setor da construção já tinha encontrado, por si mesmo, uma solução: a da utilização em massa das agências de temporários e dos CDD (Contratos por Tempo Determinado), que tornaram inúteis os contratos por canteiro.

Atualmente, a França possui dezenove tipos de contrato de trabalho, sob a responsabilidade do Ministério do Emprego, da Coesão Social e da Moradia (Druck, 2007). Seis desses tipos se destacam. São eles: o CDI (Contrato de Trabalho de Duração Indeterminada); o CDD (Contrato de Trabalho de Duração Determinada); o Contrato de Trabalho Intermitente; o Contrato de Trabalho Temporário; o CNE (Contrato para Novos Empregos); e o CI-RMA (Contrato de Inserção: Renda Mínima e Atividade). A lei que viabilizou a utilização das agências de temporários, no seu início, foi pensada como uma forma de minimizar a informalidade e combater o desemprego. Atualmente, entretanto, como demonstraremos, essas agências são, na verdade, uma forma de legalizar a "precarização", sobretudo dos imigrantes clandestinos, para os quais os seus efeitos são ainda mais perversos.

Os contratos temporários, realizados através das agências têm, por lei, o mesmo estatuto que os chamados CDD, no ponto em que estabelecem que devem ser assinados até quarenta e oito horas após o início do trabalho, predizendo 
o fim da empreitada. Contudo, o que, de fato, acontece, de uma forma ilegal (mas muito comum nessas agências), é que tais contratos não preveem o fim da missão, nem são entregues ao trabalhador, o que faz com que ele fique à mercê da demissão a qualquer momento, sem nenhuma garantia de regularização posterior. Teoricamente, as agências de temporários são as fornecedoras de mão de obra para os canteiros. Na prática, todavia, a contratação se dá por outros meios. Comumente, os chefes dos canteiros possuem seus próprios grupos fixos de trabalhadores, que os acompanham nas obras. Assim, quando há a necessidade de novos operários, eles são indicados pelos próprios trabalhadores que já se encontram no canteiro de obras. Trata-se de uma prática de recrutamento através de redes sociais informais (Lima, 2006). Assim, as agências se tornam meras intermediárias na contratação dos trabalhadores, com a única vantagem de promover, para as construtoras, a possibilidade de descarte do trabalhador a qualquer momento, sem quaisquer custos envolvidos no processo de demissão.

No setor de construção francesa, são as empresas de temporários que acabam por assumir, completamente, os riscos associados às práticas do trabalho ilegal. Com a possibilidade de recorrer às agências, as construtoras conseguem contornar as obrigações legais, transferindo para elas todos os riscos envolvidos nos vários tipos de contratos feitos de forma ilegal. As obrigações legais, então, têm de ser cumpridas integralmente por essas agências, as quais, muitas vezes, também as ignoram. O que se pode concluir é que as empresas de temporários acabam por "organizar" a precariedade. Se, pela lei, elas são obrigadas a fornecer um trabalho de tempo determinado, no cotidiano, devido às práticas ilegais por elas mesmas cometidas, acabam por fornecer um trabalho de tempo indeterminado, preservando, para a empresa utilizadora, a possibilidade de se desvencilhar do trabalhador quando quiser. O que parece mais estranho é que o trabalhador sans papier, ou seja, aquele que não tem autorização de permanência no país, uma vez vinculado às agências de temporários - seja por meio da apresentação de papéis falsos, seja por meio de uma falsificação oferecida pelas próprias agências -, passa a ter as obrigações tributárias e a ser possuidor de todos os direitos trabalhistas. Com isso, o imigrante passa a possuir uma documentação que regulariza, ainda que precariamente, sua situação ilegal no país.

A média de duração do trabalho temporário na construção civil, na França, é de seis semanas. No canteiro pesquisado, entretanto, pôde-se notar a presença de trabalhadores temporários que se encontram nessa situação há muitos anos. São temporários que, apesar dessa condição, estabelecem uma relação duradoura de fidelidade, seja com a agência, seja com a construtora, da qual permanecem reféns, sujeitos a uma demissão a qualquer momento. Muitas vezes, continuar temporário se torna uma escolha do trabalhador, pois o rendimento líquido dos temporários é maior do que o dos contratados, uma vez que do seu salário não são abatidos os direitos trabalhistas. Para os imigrantes, cujo objetivo principal é o acúmulo rápido de dinheiro, manter-se na condição de temporários se mostra uma estratégia desejável. Muitos deles argumentam, além disso, em favor da sensação de liberdade trazida pelo trabalho temporário, que lhes permite viajar aos seus países de origem, ou lembram as vantagens de poderem acionar o seguro desemprego ou trabalharem clandestinamente. Também os trabalhadores brasileiros com contrato por produtividade ("a metro") valorizam essa liberdade, e, com argumentos muito parecidos, pensam na possibilidade de buscar outras atividades, preservando a autonomia no trabalho e na vida. No caso brasileiro, os trabalhadores mais jovens preferem o trabalho por produtividade, e os mais velhos, o trabalho formal. Na França, a preferência não se dá em relação à idade, mas em relação à condição de estadia. Mesmo com a grande instabilidade, o trabalho temporário possui, para o imigrante, a vantagem de lhe proporcionar maiores rendimentos, sendo isso o que mais interessa para seu projeto de vida, voltado, na grande maioria dos casos, para o retorno ao país de origem. Na França, 
ao contrário, os imigrantes já estabelecidos, ou os próprios franceses, valorizam o trabalho registrado, que lhes garante maior estabilidade.

Assim, o trabalho temporário, como estratégia para acionar o seguro desemprego, é largamente utilizado, na França, principalmente, pelos estrangeiros, visando à ampliação de seus rendimentos. Para os imigrantes, a ausência de documentos não é vista como um empecilho, já que as possibilidades de trabalho clandestino são várias entre as pequenas prestadoras de serviços. Nelas, a falsificação ou mesmo o aluguel ou empréstimo de documentos são práticas recorrentes entre os trabalhadores. Com documentos falsos, eles se dirigem às agências de temporários, as quais, sem verificar a sua autenticidade, e na certeza de não serem fiscalizadas, enviam o trabalhador para a empresa demandante do serviço. É o que relata Imane, um servente de pedreiro argelino de quarenta e dois anos, entrevistado durante a pesquisa de campo:

- Eu vou te falar um negócio, mas você não pode falar aqui não, hein: há uns três anos, eu trouxe um primo meu da Argélia. Aqui, eu dei meus documentos a ele e ele levou na agência de temporários. E com isso foi normal, ele trabalhou e pôde pegar o seguro desemprego, normal.

Perguntado sobre se agência havia verificado se era verdadeiro ou falso o documento, Imane responde:

- Não, nada, nada. E ele trabalhou bem, ele trabalhou um ano com estes documentos, como jointer [trabalhador especializado em acabamento, nas empresas de gesso], sem nenhum problema. Depois ele pegou o seguro desemprego normal, é tudo. Isso muita gente faz aqui, mas eu só fiz porque estava na família.

Por fim, ponderando sobre os possíveis problemas com a fiscalização, o imigrante disse:

-Ele trabalhou aqui um ano, com os meus documentos. Depois, ele comprou um carro e foi embora, normal. Ele ficou muito contente. Agora, se descobrem, vão os dois pra prisão, eu mais do que ele. Porque agora está mais difícil fazer isso; antes era mais fácil. Eu fiz, mas já tem três anos. Eu não fiz isso de graça não, ele me dava duzentos euros a cada mês. É interessante pros dois, porque eu ganho uma porcentagem e ele ganha o chômage [seguro desemprego], que dá quase mil euros por mês, durante um ano. Eu faço isso também: trabalho um tempo, pego o chổmage e depois eu trabalho au noir ["no negro"]. No final do mês, dá bastante dinheiro. Isso é obrigatório; pra ganhar mais dinheiro, tem que fazer isso.

Todas essas ilegalidades praticadas pelas agências de temporários - da ausência de verificação da autenticidade dos papéis à produção de documentos falsos para os trabalhadores poderiam colocá-las em situação irregular diante da fiscalização e torná-las sujeitas a punições. No entanto, isso - segundo Jounin (2008) - raramente ocorre, de modo que tais agências quase nunca são fechadas. Os trabalhadores imigrantes, legalmente fragilizados, com documentos de permanência provisória, ou, muitas vezes, sem quaisquer documentos, economicamente necessitados de trabalho, possuem uma pequena capacidade de fazer valer os seus direitos. Os temporários do canteiro são convocados por várias agências diferentes, de maneira a dificultar a emergência de um coletivo de trabalhadores organizados, que apresentem, por exemplo, reivindicações unificadas. Nesse sentido, as incertezas impostas pelo trabalho temporário constituem uma potente arma de controle do trabalhador.

\section{A concentração étnica nos ofícios}

A presença maciça de imigrantes em funções subalternas, no canteiro pesquisado, revelou uma ausência de estrangeiros em postos mais elevados da hierarquia, como o chefe do canteiro e o chefe de equipe, ambos franceses. Com exceção de um pedreiro aprendiz, todos os demais operários eram imigrantes ou de origem estrangeira.

Parece ser unanimidade, entre os trabalhadores, que a presença maciça de estrangeiros na construção civil ocorre por causa do desinteresse da maioria dos franceses pelos trabalhos braçais dos canteiros de obras. Grande parte dos migrantes chega com o objetivo muito bem definido de ali trabalhar por algum tempo, para 
retornar a seu país de origem com algum recurso. Alguns possuem metas estabelecidas e claras do quanto precisam para realizar algum projeto em seus próprios países. É raro, pois, encontrar algum imigrante, na construção, com pretensões de se estabelecer definitivamente na França.

As atividades exercidas pelos imigrantes, no canteiro pesquisado, possuem estreita relação com a sua origem. Os portugueses, que fazem parte de uma migração mais antiga, iniciada ainda na década de 1970, encontram-se atualmente vinculados a ofícios mais especializados, até mesmo ocupando cargos de chefia, como os de chefes de canteiros e de equipes, ou possuindo pequenas prestadoras de serviços para a empresa principal - são os chamados “artesãos”. Os magrebinos (marroquinos, argelinos e tunisianos), em sua maioria, são trabalhadores de ofícios como carpinteiros (coffreurs), armadores (ferrailleurs) e pedreiros de acabamento, também podendo ocupar a posição de serventes (manœuvres). Os imigrantes africanos subsaarianos, negros em sua grande parte, são manœuvres, responsáveis pelos trabalhos mais pesados do canteiro. As próprias agências de trabalho temporário trazem consigo uma imagem da nacionalidade correspondente cada função. Essa concentração étnica nos ofícios, entretanto, não é resultado de uma organização estruturada. O que se observa é um recrutamento descentralizado dos profissionais, no qual atuam a agência de temporários, o chefe do canteiro e a empresa utilizadora. A precarização dos contratos faz com que se institua, entre os trabalhadores, uma concorrência que impede a concentração absoluta de uma etnia em determinados ofícios. Como afirma Jounin (2006), não existe uma política centralizada e que segrega, nem uma estruturação prévia, mas há uma conjunção de elementos que acaba por explicar a tendência da concentração étnica.

Um desses elementos diz respeito à condição de estadia. Como demonstra o mesmo Jounin (2006), no caso dos ferrailleurs, para quem as condições de trabalho são as mais precárias e mal remuneradas, as empresas optam por procurar os tra-

balhadores legalmente mais vulneráveis, ou seja, os sans papier (sem documentação legal), ou aqueles que têm apenas uma permissão precária de estadia. Alguns grupos étnicos se encaixam nessa situação, em especial os magrebinos e africanos subsaarianos, dos quais um grande contingente se submete à subcontratação por intermédio das agências de temporários. Outra situação completamente diferente é a vivenciada pelos trabalhadores oriundos da Comunidade Europeia, notadamente os portugueses, que, desde 1991, possuem o direito de livre circulação nos países europeus. Esse direito veio a confirmar uma preferência antiga e menos formalizada do Estado francês em relação aos imigrantes de Portugal, considerados mais “assimiláveis" do que outros. Isso explica as vantagens dos portugueses, que ocupam cargos de chefia e posições mais estáveis, em contraste com a situação vivida pelos demais imigrantes.

Um segundo elemento étnico no recrutamento do trabalho na construção diz respeito à gestão racista da mão de obra. De fato, o canteiro representa um espaço onde diversas formas de racismo são praticadas, formas que, aliás, não se limitam aos canteiros de obras, encontrandose presentes também nas agências de temporários e nas empresas utilizadoras.

Compartilhado pelos recrutadores, o racismo se instituiu como parte do senso comum. Colocar-se contra isso representa correr um risco comercial. Não há interesse algum em mudar esse quadro, do qual Jounin fornece alguns traços:

... se um indivíduo de origem magrebina, sem
qualificação, apresenta-se a uma agência de tem-
porários, ele será enviado para a empresa
utilizadora como ajudante de armação de ferra-
gem; se o indivíduo é um maliano, como ajudan-
te simples. A agência conclui que os magrebinos
são “feitos para” a armação e os malianos “feitos
para” serem serventes. Ela terá razão, uma vez
que foi a própria agência que os fez armadores
ou serventes (Jounin, 2006, p.5).

O terceiro elemento tem a ver com o recrutamento através das redes sociais informais, por meio das quais os trabalhadores vinculados a uma empresa indicam outros indivíduos para os trabalhos. O processo da imigração é sempre viabilizado 
por outros trabalhadores já imigrados, de mesma nacionalidade, através de redes de informações que não só possibilitam a obtenção de trabalho - quase sempre, no mercado "negro" (clandestinamente) , como, também responsabilizam-se pela recepção dos novos migrantes. Grande parte deles, ao chegar, não possui autorização de permanência no país (carte de séjour), o que faz com que as maiores oportunidades se concentrem no mercado "negro", ou mesmo nas agências de temporários, com as quais o estrangeiro se vincula, seja através de documentos falsos, seja usando documentos emprestados por algum concidadão.

O fato de os grupos já estabelecidos possuírem maior facilidade em arrumar emprego para outros trabalhadores, tais como membros da família e amigos, também estabelece uma discriminação indireta, uma vez que grupos novos, dentro de um determinado ofício, não possuem grandes possibilidades de fazer indicações. Nos setores em que determinados grupos étnicos se tornam a maioria, por serem os pioneiros, o recrutamento tende a se dar por meio de uma rede de contatos pessoais, o que produz nichos étnicos dentro de um mesmo ofício. Nesses casos, tais nichos étnicos não só viabilizam oportunidades de empregos, mas ensinam as competências necessárias, supervisionando o desempenho do indivíduo.

\section{Qualificação e trabalho temporário}

A pesquisa de campo, realizada na França, revelou uma dimensão muito singular da qualificação profissional, no meio da construção civil. Mesmo que este estudo não tenha focalizado diretamente as agências de temporários, as entrevistas com os trabalhadores, dentro e fora dos canteiros, mostraram alguns indícios sobre como essa intermediação de mão de obra vem definindo as qualificações. As agências, atualmente, reconfiguram as atribuições de qualificação, o que contribui para a reconstrução de um mercado de trabalho, no qual as regras burocrá- ticas ou convencionais passam a ser, cada vez mais, minimizadas.

Para se compreender a relação entre as agências de temporários e a qualificação, é preciso, primeiro, entender que o trabalho temporário significa um modelo de emprego descontínuo e incerto, que se distingue, inclusive, do CDD (Contrato de Tempo Determinado), do qual se aproxima por possuir a mesma forma jurídica, com um empregador intermediário entre o trabalhador e a empresa que utiliza os serviços. As agências, como intermediárias, possuem várias funções, dentre as quais a de executar as ilegalidades, como bem definiu Jounin (2008). Pela legislação, as funções de empregador são divididas entre a agência de temporários, que conserva as prerrogativas de quem emprega, e a empresa que se utiliza dos serviços, a responsável pelas condições de execução dos trabalhos. Na prática, essa distinção, baseada na divisão entre o empregador legal e o de fato, é fluida, permitindo diversos arranjos.

As transformações devidas às agências de temporários refletem duas tendências, aparentemente contraditórias: de um lado, elas induzem especializações, ao criarem novas fronteiras no interior dos ofícios, até então considerados unificados; de outro, produzem uma homogeneização no interior de um determinado ofício, através da supressão dos níveis de qualificação. O ofício de coffrage, no qual certos trabalhadores são os responsáveis pelas fôrmas de concretagem de vigas, pilastras e paredes, é um exemplo revelador. As agências procuram, especificamente, os bancheurs, trabalhadores especializados em uma parte somente da coffrage, qual seja, a da montagem mecânica de fôrmas de aço para a concretagem. Tal fato ocorre também em outros ofícios, como, por exemplo, no de ferraillage, uma vez que as agências procuram somente os attacheurs, profissionais responsáveis por uma pequena parte do trabalho de amarração das armaduras de ferro. O efeito dessas reduções leva à limitação do "saber fazer" do trabalhador, já que se parcela o ofício, reduzindo, assim, as pos- 
sibilidades de uma absorção mais ampla dos saberes relacionados a um determinado trabalho. Como consequência, reduzem-se o reconhecimento e a remuneração do empregado. Chama a atenção, ainda, o fato de que tais serviços, muitas vezes simplificados, não são destinados aos trabalhadores menos qualificados, pois, se alguém mais capacitado não encontra uma missão correspondente à sua qualificação, acaba tendo de realizar atividades que estão aquém de sua capacitação.

Para selecionar e recrutar trabalhadores, as agências utilizam o Certificado de Trabalho ou a ficha de pagamento fornecida pelo empregador precedente. Esses documentos atestam a qualificação do candidato, sendo primordiais para que ele se insira em uma nova missão. É através deles que tanto as agências de temporários quanto as empresas exercem a função de empregador, produzindo efeitos contraditórios em relação às oportunidades que surgem para o trabalhador, seja fechando-as, seja abrindo-as.

Os trabalhadores, na França, ao mesmo tempo em que buscam ampliar a sua qualificação, procuram obter o reconhecimento de um ofício que lhes permita um maior ganho. No entanto, eles estão sempre à mercê da dualidade que existe entre as agências de temporários e as empresas que fazem uso dos serviços prestados. Se as agências não podem classificar o trabalhador sem antes obter o reconhecimento da empresa, essa última deve atestar as aptidões do empregado para exercer determinado ofício. As empresas, entretanto, sempre alegam que precisam de um certificado de trabalho fornecido somente pelas agências, para autorizar o trabalhador a exercer o ofício no canteiro. As agências têm um enorme interesse em preservar o vínculo com o trabalhador, pois ele é o objeto central do seu trabalho. Tendo isso em vista, abusam das promessas de, na missão seguinte, dedicar um maior empenho em relação à classificação do empregado, exatamente como fazem os empregadores brasileiros. No entanto, como afirmam vários temporários, o interesse primordial das agências é o de preservar a esperança dos trabalhadores, sem, de fato, cumprir qualquer promessa. Apesar de conscientes disso, para muitos, a estagnação de sua classificação não é motivo suficiente para se desvincularem da agência, pois, apesar da execução de tarefas abaixo de sua real qualificação, tais indivíduos estão integrados ao núcleo estável das agências, através das quais conseguem missões regulares e certas, o que não deixa de ser muito apreciado.

O blefe e a mentira também fazem parte das estratégias para ampliar a qualificação do trabalhador. São procedimentos usados tanto pelas agências de temporários quanto pelos trabalhadores, visando à obtenção do certificado de trabalho, o que permite a um empregado procurar, em outras agências, um serviço mais qualificado. Eis o que fala Imane, o servente de pedreiro argelino, sobre uma de suas tentativas de conseguir uma ocupação através de uma agência de temporários:

No meu CV, eu marquei pedreiro, mas não qualificado. Depois, eu coloquei carpinteiro, porque eu já fiz um pouco, eu trabalho, mas não sou um bom profissional nesta área. Eu coloquei ofícios que eu já tinha feito, mas não profissionalmente.

Perguntado sobre se haveria algum tipo de verificação da qualificação pela empresa, o imigrante responde:

Tem não, não tem nada, nada... Muita gente faz isso. Mas tem que fazer pelo menos um pouco. Aqui na Franca você tem que mentir um pouco, senão você nã̃o trabalha na construção, porque, na construção, eles perguntam se você tem experiência. Se você não tem, eles dizem não; então, a gente é obrigado a mentir. Você é obrigado a mentir um pouco, é obrigado. Todo mundo faz isso.

Nas construções pesadas (gros œuvre), existe um sub-reconhecimento das qualificações. Mesmo os trabalhadores que, na prática, conseguem “subir” na estrutura hierárquica dos ofícios, somente desfrutarão do reconhecimento formal de uma nova classificação após severas avaliações, que duram meses ou mesmo anos, ainda que se baseiem sobre o ofício que já desenvolvem cotidianamente no canteiro. Muitos chefes de equipes ou de canteiros, por exemplo, iniciaram-se nessas 
funções antes de obterem a formalização correspondente. Frequentemente, o trabalho realmente executado pelo trabalhador não corresponde à sua qualificação. Para os trabalhadores habilitados, também se torna comum a execução de tarefas menos qualificadas, pois, durante o processo de trabalho, pode ocorrer de não haver postos correspondentes para todos. No trabalho temporário, é praticamente impossível acontecer essa correspondência (exceto nos casos de blefe e de mentira), uma vez que a flexibilidade das agências de temporários permite reajustar as qualificações aos postos correspondentes. Para os trabalhadores, então, os certificados de trabalho exigidos pelas agências funcionam apenas como indicadores de sua capacidade, e não como um título que garanta seu direito a certos postos, em acordo com uma qualificação estável.

Assim, constata-se que as agências de temporários vêm "apagando" parcialmente as regras tradicionais de reconhecimento das qualificações, substituindo-as por relações desvinculadas das negociações coletivas. O trabalho temporário, em tese, continua preservando as convenções, mas o que ocorre, na prática, é um uso particular delas. O fato é que a Convenção Coletiva não consegue mais desempenhar o papel de classificadora dos empregos, de detentora da determinação das tarefas, como tampouco o de fonte estabilizadora dos trabalhadores nos ofícios alcançados, pois não é mais capaz de evitar o regresso a trabalhos menos qualificados, nem de estipular o valor do trabalho, que é mesmo negociado caso a caso. Nesse contexto, a obtenção de uma qualificação aparece muito mais vinculada às estratégias paternalistas de um "favor" do que a uma real avaliação dos méritos dos trabalhadores.

O rendimento das agências de temporários se vincula, exclusivamente, à quantidade de pessoas que elas enviam para as empresas utilizadoras. Quanto maior o número de trabalhadores qualificados, maior será a quantidade de benefícios atribuídos à agência. Pelos relatos dos trabalhadores, entretanto, percebe-se o seguinte: se, por um lado, os serventes representam, em termos de retorno financeiro, para as agências, muito menos que os trabalhadores qualificados, por outro, os custos sociais dos trabalhadores menos qualificados são menores. Com isso, a obtenção da classificação do trabalhador acaba se realizando por meio de um cálculo econômico das agências, em seu próprio benefício. Tal fato mostra que a dimensão suplementar da qualificação dos trabalhadores não aparece propriamente como um valor em si, nem referência para a distribuição de salários, mas como elemento atrelado às estratégias econômicas das agências.

\section{A prestação transnacional de serviços}

A prestação transnacional de serviço é uma forma de subcontratação do trabalho, que, legalmente, existe há muito tempo, mas que só passou a apresentar um grande crescimento nos últimos dez anos. O setor da construção civil tem uma característica definidora: a de produzir onde se consome o produto. É impossível, para as empresas construtoras, o deslocamento da produção, isto é, a transferência de serviços para outros lugares, com o aproveitamento de mão de obra local, como podem fazer outros setores de atividades, como a indústria de têxteis e as metalúrgicas. Utilizar a concorrência internacional, no caso da construção civil, significa fazê-la vir ao país onde serão utilizados os serviços. O que acontece, no entanto, na prática, é que uma empresa, por exemplo, portuguesa, que vai prestar serviço para uma construtora, na França, não existe, de fato, em funcionamento, em Portugal. Ou, se existe, mantém somente alguns empregados como forma de regularizar a "exportação" de trabalhadores, que ganham, na verdade, o salário português, com toda a cotização social portuguesa, em um tipo de subcontratação que representa um barateamento de custos, para a empresa que se utiliza de tais serviços. Isso, contudo, é considerado ilegal. O problema é como fiscalizar, no país de origem, a existência real da empresa. Joaquim, um pedreiro português, fornece um relato da situação em Toulouse: 
Aqui em Toulouse têm muitas empresas de Portugal, e agora tem muita polonesa também. Elas vêm aqui trabalhar e trazem muita gente de lá. E eles ganham o salário de lá. Eles moram todos juntos, tudo apertado em T2 [apartamento de dois cômodos]. Moram cinco, seis, sete, em um lugar de dois lugares. Eles andam sempre juntos, e não conversam porque não falam nada em francês. Eles vêm aqui só pra trabalhar e não gastam nada, só vêm pra juntar dinheiro. Eles mandam tudo pro seu país. Isto tem muito, muito.

Os empregados vinculados às empresas de países de fora da Comunidade Europeia não possuem o direito de trabalhar para uma firma local. Assim, qualquer desentendimento no trabalho deve ser evitado, pois os trabalhadores estão impedidos de procurar serviços em outro lugar, uma vez que não têm permissão para permanecer legalmente no país. Estão presos a uma empresa, e, por isso, são considerados pelos chefes como empregados dóceis e de fácil lida. Os trabalhadores deslocados têm autorização de permanecer na França somente enquanto estão trabalhando. Se quiserem abandonar o serviço, precisam voltar ao seu país de origem, ou entrar para a clandestinidade. É desse modo que a prestação transnacional de serviços se torna um mecanismo de incentivo às irregularidades, contribuindo, em parte, para a existência de trabalhadores sans papier.

Tal situação demonstra bem que os pro-

\section{Informalidade e subcontratação: o caso} brasileiro

No Brasil, a construção civil executa, tradicionalmente, tipos de contrato de trabalho que divergem das normas estabelecidas pela Conven- ção Coletiva do setor, que são regidas pelas formas legais baseadas na CLT (Consolidação das Leis Trabalhistas). A clandestinidade nas obras brasileiras é uma realidade há muito tempo conhecida, sendo os contratos informais - vistos como normais - praticados por grande parte das empresas do setor. A naturalidade das práticas se revela com o fato de os trabalhadores não possuírem nenhum receio em falar dos contratos, expondo, em detalhes, as formas segundo as quais foram estabelecidos. A mesma naturalidade, contudo, não se traduz nas falas dos engenheiros e dos encarregados responsáveis pela gestão do canteiro. Ainda que se trate de práticas bastante conhecidas, a abordagem do tema, nas entrevistas e nas conversas informais com os dirigentes, sempre gera desconforto.

As ilegalidades, bastante diversificadas, são estabelecidas através de acordos orais. Além da clandestinidade integral dos contratos de trabalho, comum entre os empregados que ganham por produtividade, por empreitada, ou entre os que estão vinculados aos empreiteiros denominados "gatos", encontram-se várias formas de clandestinidade parcial.

Uma das práticas mais comuns de clandestinidade integral está presente no atraso da assinatura da carteira de trabalho. A empresa, normalmente, pede ao trabalhador para trazer a carteira já no primeiro dia de serviço, com a promessa de registro. A expectativa da assinatura, sempre adiada, pode durar meses, em alguns casos com a justificativa de que o trabalhador ainda estaria em período de teste, para uma possível classificação em um ofício, como é comum entre os serventes. Quando questionados sobre isso, a resposta dos trabalhadores é quase sempre a mesma: “... ele me disse que vai assinar, mas até agora...”. Frequentemente, sobretudo quando o trabalhador começa em um canteiro já avançado, em que, segundo os dirigentes, a presença da fiscalização é menos provável, a obra termina sem que o esperado registro formal aconteça. Entre os trabalhadores que possuem contratos por produtividade (“a metro"), permanecen- 
do autônomos, vive-se situação semelhante. Nesse caso, a assinatura da carteira visa a evitar multas, em uma eventual fiscalização, mas está dissociada das garantias dos direitos trabalhistas.

De fato, a carteira de trabalho funciona, no canteiro, como um elemento contraditório. Sendo ela correspondente ao currículo profissional dos trabalhadores - em que estão registrados, além do seu ofício, as empresas nas quais trabalharam e o seu tempo de permanência-, um registro de curta duração, com menos de três meses, por exemplo, pode significar algum problema do trabalhador, associando-o ao rótulo de "biscateiro". Por isso, quando o trabalho sem a assinatura da carteira aproxima-se do fim das obras do canteiro, ou quando os serviços são de curta duração, os próprios trabalhadores preferem não ter o registro, o que significaria marcá-lo com uma "carteira suja", podendo gerar problemas, em futuros empregos. Os empregadores, então, tendem a adiar o registro dos trabalhadores, que, em alguns casos, permanecem nas obras durante meses, sem nenhum vínculo formal.

Outra ocorrência comum acontece quando a empresa compele o trabalhador a tirar uma nova carteira de trabalho. Tal fato ocorre, sobretudo, em relação aos funcionários que possuem experiência profissional registrada, e tem como objetivo principal camuflar as ilegalidades cometidas. As seguintes situações são as mais comuns, no que diz respeito à "nova" carteira de trabalho: i) o salário do emprego anterior era maior do que o proposto pela empresa, no ato da contratação; ii) a empresa admite trabalhadores com categoria profissional diferente daquela registrada na carteira; iii) há excesso de registros de curta duração, o que pode caracterizar aquela "carteira suja”, acima referida. Tudo isso faz com que seja muito comum, para um trabalhador do setor, possuir várias carteiras profissionais, algumas delas com registros fraudados. Paradoxalmente, a carteira de trabalho é um documento e referência central para a empresa, no processo de seleção. O engenheiro-proprietário, Neilor, explica como recruta e o que analisa na carteira de trabalho dos candidatos:
Eu normalmente olho o que aconteceu, quanto tempo o cara está sem fichar, quanto tempo ficou fichado, nas últimas empresas. Passaram, outro dia, duas pessoas aqui, pra trabalhar de servente. Eu peguei a carteira deles, e um estava até meio alcoolizado. Fui conversar com eles. Peguei a carteira de um e vi que ele tinha um mês numa empresa, dois meses na outra, um mês numa terceira empresa. Aí você desconfia. [...] Muita gente, quando vem trabalhar aqui, fala: "o meu serviço aqui é só de um mês". A maioria deles tira uma carteira nova, está limpinha. Você põe aquele registro de trinta dias, de quarenta e cinco dias, que é o contrato de experiência, por exemplo. Às vezes, o cara não quer isso, fica com medo de chegar na próxima obra e a pessoa não aceitar, porque ele tem somente trinta dias de um término de contrato. O cara fica com medo.

O que se percebe aqui é uma evidente contradição. Ao mesmo tempo em que as empresas, com raras exceções, não oferecem estabilidade a seus profissionais, elas exigem trabalhos anteriores estáveis, registrados em carteira, como atributo necessário à admissão. Os contratos de experiência, como o citado por Neilor, indicam outra forma utilizada para se adiar o registro dos trabalhadores. Por lei, o contrato de experiência - que não pode durar mais de três meses - só pode ser usado para profissionais que não tiveram registro em carteira, em um determinado ofício, durante os últimos doze meses. São os serventes os mais contratados a título de experiência, e os que mais permanecem nessa situação por tempo indeterminado, pois os empregadores, quase sempre, adiam a sua legalização. Teoricamente, o contrato de experiência seria uma forma de testar a eficiência do profissional, antes de ele ser contratado, formalmente. Entretanto, no caso de um servente, por exemplo, éóbvio que não são necessários três meses para a averiguação das capacidades, pois se trata de um profissional em funções eminentemente servis. $\mathrm{O}$ fato é que o contrato de experiência funciona, essencialmente, para adiar a formalização.

\section{O Contrato por produtividade ("a metro")}

O contrato por produção, denominado, no canteiro, como "a metro", é a forma de trabalho 
clandestino mais comum, na construção civil, na região Metropolitana de Belo Horizonte (RMBH). Nesse tipo de contrato, muito comum entre os pedreiros de acabamento, de alvenaria, carpinteiros, armadores e gesseiros, a recompensa do trabalhador corresponde à quantidade de metros quadrados produzidos, durante o mês. Nas entrevistas a priori, ele figura como o tipo de contrato preferido pelos trabalhadores, uma vez que seus ganhos podem chegar a até três vezes mais que o "salário do sindicato". "Trabalhar a metro” é desejado por grande parte dos trabalhadores de ofício. Não se trata, todavia, de um contrato oferecido a todos, o que faz com que os detentores dele possuam um status de excelência profissional. Normalmente, a justificativa do empregador para a utilização de tais contratos é a curta permanência dos trabalhadores no canteiro, o que torna oneroso registrá-los.

As vantagens do contrato "a metro", para o empregador, são muitas, e de vários tipos: i) redução dos custos trabalhistas, pois não se pagam encargos, tais como o décimo terceiro salário, férias, cesta básica, vale-transporte, e, sobretudo, os encargos relativos ao processo de demissão; ii) aumento da produtividade; iii) rapidez nos serviços, decorrente da transferência, para o trabalhador, da responsabilidade de ele mesmo construir seu salário, dispensando o controle relacionado à produtividade, muito comum entre os registrados. Ou seja, como o domínio sobre "o fazer" pertence aos trabalhadores, e a via autoritária não garante um controle eficaz da produção, esses "incentivos" se tornam, de fato, importantes; iv) ampliação da previsibilidade de custo, pois se pode orçar a obra antes de começá-la.

Para os trabalhadores, o contrato "a metro" se tornou a única possibilidade de ampliação de ganhos, pois, em vários aspectos, encontram-se submetidos a uma prática que, além de negar seus direitos trabalhistas, produz instabilidade, o que não é desejável, especialmente, pelos trabalhadores mais velhos. Isso se confirma através do depoimento de Jorge, um pedreiro de acabamento de cinquenta e três anos, quando questionado so- bre se sua preferência seria trabalhar "fichado" (com registro formal em carteira) ou "a metro":

Prefiro trabalhar fichado, claro! Com certeza. Trabalhar "a metro" é muita insegurança. É um sofrimento de uma hora você não encontrar "a metro". Aí, eu prefiro ficar pelo menos uns seis, sete meses, devido ao meu INSS, em um serviço digno.Você está ali todo dia, aquele horário. Você pode fazer dívida, você pode fazer um compromisso com aquilo ali.Todo mês você tem ele. Saindo dali, eu tenho o meu seguro desemprego, tenho meus acertos. Não é ruim trabalhar fichado, não é ruim. Só que, pra quem trabalha fichado, ganhando aí oitocentos reais por mês, não dá.

As vantagens de trabalhar por produtividade, uma vez que os ganhos, realmente, aumentam, não parecem ser suficientes para que esse trabalhador deixe de almejar a estabilidade. Frente à elevada instabilidade, na construção, Jorge revela uma estratégia, relacionada ao ritmo do trabalho, que visa a minimizar as incertezas do dia a dia. Nessa estratégia, ganha destaque o controle que possui do seu ofício:

Esse negócio do ritmo, no trabalho "a metro", é o
seguinte: não adianta eu trabalhar muito e ganhar
muito, que, depois de um tempo, o serviço aqui
acaba, e eu tenho que ir procurar outro serviço; e
corre o risco de não achar "a metro". Eu faço o
seguinte: se eu vejo que está ruim de serviço, na
praça - não pode nem falar isso aqui não [risos]
-, eu vou num ritmo que dá pra tirar um pouco
mais do que o “salário do sindicato". Mas se esti-
ver tendo muita obra, e as firmas estiverem pre-
cisando de serviço de acabamento - porque eu
conheço muita gente aqui que mexe com obra -,
aí eu pego em um ritmo mais pesado. Aí dá pra
ganhar mais, e até juntar um pouquinho, sem fi-
car pensando que não vai ter trabalho.

As afirmações do pedreiro, contudo, não parecem corresponder à opinião dos trabalhadores mais jovens, e, sobretudo, dos aspirantes ao contrato "a metro", que, no canteiro pesquisado, representam a maioria. Pouco inclinados a se manterem na situação de assalariados (com salário mensal de $\mathrm{R} \$ 778,00)$, os mais jovens tendem a se lançar ao encontro das diversas variantes do trabalho clandestino e precário, fundamentados na recusa ao valor irrisório do "salário do sindicato" e nas poucas vantagens que podem esperar do Estado.

A certeza de que serão “obrigados” a estabelecer um acordo com a empresa quando do pro- 
cesso de demissão, em relação ao recebimento da multa rescisória, contribui para fortalecer o desinteresse dos operários quanto à formalização. Eis mais um motivo para buscar trabalhar por produtividade, o que, nos últimos tempos, devido ao crescimento do setor, torna-se ainda mais atraente pela facilidade em se conseguir outra colocação no mercado quando findam os trabalhos, no canteiro.

Tal ideia é corroborada pela colocação de Clério, de trinta e quatro anos, sobre o trabalho por produtividade:

É mais interessante, porque, se você trabalha, numa firma dessa aí, um ano, o direito que você tem pra receber não dá mais do que dois mil reais. E olha lá se dá, ainda, pelo acordo que eles fazem. Então, você, trabalhando na produção, não, você já está tirando seu salário, já está tirando tudo que você tinha o direito de receber, já está tirando muito mais.

A transferência da responsabilidade para o indivíduo, no momento da elaboração de seu salário, não considera as contingências que envolvem o trabalho nos canteiros. O setor da construção civil, com efeito, possui a especificidade de estar submetido rotineiramente a várias contingências. Uma delas - nada desprezível - diz respeito às condições meteorológicas. Outros fatores que também interferem na produtividade, apenas para lembrar alguns, seriam os atrasos na compra de materiais, a ausência ou realocação de ajudantes e o refazer do serviço quando se constatam falhas nos trabalhos executados, o que sempre gera insatisfações.

Outra maneira de trabalho "a metro" é a vivenciada pelos trabalhadores formais, em um contexto no qual a inter-relação entre formalidade e informalidade se torna muito clara. $\mathrm{O}$ trabalho "a metro", aqui, é um incentivo para o trabalhador ampliar seu rendimento, ainda que aumentando, e muito, a sua quantidade de serviço diário. Nesse caso, o operário registrado na empresa e com alguns direitos assegurados recebe uma cota de trabalho, em metros quadrados, que deve ser feita por dia. Se ele produzir além da cota prevista, recebe por produtividade, ou seja, pela quantidade de metros quadrados exe- cutados em uma semana de trabalho.

A principal crítica dos trabalhadores a esse último tipo de contrato refere-se ao fato de que a cota já é muito elevada, e o ganho por produtividade nunca chega a representar um percentual maior que $10 \%$ do salário fixo. O que se percebe, então, é que se trata de mais uma estratégia de aumento da produtividade, sem aumentar muito o ganho do trabalhador.

\section{O Trabalho por empreitada}

Esse tipo de contrato difere do "a metro" pela forma como se estipula o valor do trabalho e pela particularidade das subcontratações. O contrato por empreitada é estabelecido entre um trabalhador de ofício e a construtora, de acordo com um preço fixo pré-estabelecido para o trabalho a ser realizado. A empreitada constitui uma modalidade muito comum, sobretudo entre os trabalhadores que permanecem na obra desde seu início, como os encanadores e os eletricistas. Pelas próprias características dos seus processos produtivos, esses profissionais não possuem atividades regulares, como os demais. Suas intervenções se desenvolvem em etapas, sempre dependentes da realização de outros trabalhos. A empreitada, então, é a forma encontrada por esses profissionais para venderem seus serviços a várias empresas, ao mesmo tempo, de modo a otimizar as horas ociosas restantes em cada canteiro. Para atenderem aos diversos canteiros, encanadores e eletricistas, por exemplo, quase sempre contam com ajudantes, às vezes, profissionais experientes, com os quais estabelecem acordos também informais.

Em ambas as formas de contrato informal impostas pela empresa pesquisada, isto é, tanto no contrato "a metro" quanto no trabalho por empreitada, ficam claras as possibilidades de o empregador burlar a legislação trabalhista, escapando dos tributos previstos por lei, transferindo as ilegalidades para terceiros e, sobretudo, garantindo o poder de demitir o trabalhador a qualquer 
momento. São poucos os casos em que o trabalhador é registrado, o que acontece, geralmente, ou por questões de afinidade com a chefia, ou porque ele pertence a um pequeno núcleo fixo da construtora. O registro na carteira de trabalho, além de ampliar a garantia de fixação do profissional na obra pelo período em que ele é necessário, protege a empresa da imprevisibilidade de uma eventual fiscalização. Nos contratos por empreitada, entretanto, os profissionais subcontratados, em sua maioria, não possuem vínculo com a construtora, ou seja, não têm qualquer registro formal. Nesses acordos informais, o profissional empreiteiro se torna o responsável pelas "pessoas que ele coloca no canteiro", assumindo riscos, como o das multas, que podem advir da ausência de registros formais ou mesmo de possíveis acidentes de trabalho. Essa é, na verdade, uma das grandes preocupações da construtora, que procura deixar sempre clara, para o empreiteiro, a sua responsabilidade frente aos possíveis problemas com a fiscalização, informando-lhe, inclusive, que, na eventualidade de autuações, as penalizações serão totalmente repassadas a ele, uma vez que, legalmente, é a Construtora a responsável por todos os profissionais que atuam em seus canteiros. Em alguns casos, sobretudo no início da obra, a construtora procede da mesma forma com os ajudantes. Ela registra todos os profissionais, mas delega ao empreiteiro todas as demais responsabilidades. Os empreiteiros, por sua vez, nunca pagam os direitos, todos negados por meio dos acordos informais.

$\mathrm{O}$ acordo entre as partes, nesses termos, faz com que o trabalhador deixe de receber os benefícios previstos em lei. O recolhimento do INSS, por exemplo, é burlado através de uma estratégia em que o contratante atribui vinte dias de falta ao trabalho, para cada um dos meses em que o trabalhador estiver vinculado à construtora. Com isso, paga-se somente o equivalente aos dez dias que, teoricamente, foram os trabalhados. A empresa paga o total referente ao mês de trabalho e, conforme acordado, o valor correspondente aos vinte dias é descontado no pagamento mensal do trabalhador. O contratante, então, deposita todo mês um determinado valor em conta, que é também descontado do contratado todos os meses.

Algo semelhante ocorre em relação ao FGTS (Fundo de Garantia por Tempo de Serviço) e à multa rescisória de $40 \%$ do valor desse fundo, obrigatória em caso de demissão de funcionários que permanecem mais de um ano com o registro na carteira - o que, diga-se de passagem, é bastante raro na RMBH. No caso da multa rescisória, existem duas práticas comuns: i) há um desconto no rendimento mensal do contratado; ii) o dinheiro da multa é entregue ao trabalhador, no próprio sindicato, quando da homologação da demissão, e, em seguida, devolvido para o empregador, veladamente. Visando a eliminar a necessidade de pagamento desse encargo e de todo o trâmite burocrático envolvido no processo de demissão - sobretudo, a homologação, no sindicato -, a empresa sempre opta por, formalmente, demitir todos os trabalhadores antes de constar um ano de registro na carteira de trabalho. $\mathrm{Na}$ prática, contudo, eles continuam a trabalhar informalmente - até o término dos serviços do canteiro. Essa parece ser a forma adotada pelas pequenas e médias empresas, fortalecendo a instabilidade e fazendo com que, depois de onze meses, os trabalhadores se vejam obrigados a acionar o seguro desemprego e a procurar outra colocação no mercado de trabalho.

Acordos informais como esses, entre trabalhador e empresa, baseados em uma série de ilegalidades, como se vê, são normalmente aceitos pelos funcionários, seja por conta da possibilidade de se aumentar o ganho mensal durante o tempo trabalhado, seja por se atrelarem às expectativas de se vislumbrarem, na mesma empresa, possibilidades de trabalhos futuros. O recurso à Justiça do Trabalho, via sindicato, é algo distante das perspectivas dos trabalhadores da construção civil, pois, em um meio social relativamente pequeno, isso poderia comprometer futuras possibilidades de trabalho. Procurar a Justiça é mesmo uma atitude rara, em um setor no qual os acordos não só contam com a conivência dos envolvidos, como também são desejados por uma parte de- 
les. O trabalhador Clério é quem afirma:

Se você sair daqui, você vai no sindicato, você pode até receber... Mas você vai mexer com Justiça, vai mexer com essas coisas, e como diz o outro, aquela porta ali, pra você, já fechou. Aqui [ele fala o nome da cidade], a gente conhece todo mundo que mexe com obra. Os engenheiros e os mestres de obra também conhecem todo mundo. Se você levar uma firma na Justiça, pronto, onde você vai conseguir trabalho depois?

As diversas formas de contratos informais existem por conta da necessidade de as construtoras reduzirem seus custos de produção. Tendo isso em vista é que elas investem na absorção instável e informal do trabalho, sem vínculos empregatícios, gerando a alta rotatividade dos trabalhadores. A possibilidade de se desvencilhar do empregado a qualquer momento, sem ter de arcar com os custos envolvidos no processo de demissão, é, de fato, extremamente atraente no setor da construção civil.

As estratégias para se burlarem as leis trabalhistas, gerando liberdade, no processo das demissões, viabilizam-se também por meio de subcontratações intermediadas por pequenos "empreiteiros" - os "gatos" -, normalmente profissionais que se apresentam à construtora para um determinado tipo de trabalho. O presidente do Sindicato dos Trabalhadores da Construção Civil da RMBH explica a estratégia:

Funciona assim: uma empresa precisa fazer um acabamento. Aí vai e contrata um gesseiro, e ele leva mais três, quatro. Aí você chega dentro de uma obra e encontra várias pessoas de ramos diferentes, tudo irregular, totalmente informal. Existe isso demais. O empresário fala: "vem cá, estou precisando que você faça um azulejo pra mim aqui!”. Vai lá e faz um contratozinho à parte com ele, sem registro nenhum. Aí, aquele azulejista chama mais um tanto pra ajudar ele. Aí, vira essa zona.

Esse relato sugere bem as estratégias das construtoras em relação à transferência, para os empreiteiros ("gatos"), das responsabilidades com os direitos trabalhistas que elas mesmas não pagam. Nesse âmbito, a empresa somente registra os profissionais, transferindo os encargos para o empreiteiro, o "gato", que passa a ser o responsável pelas eventuais multas que a construtora vier a receber devido às ilegalidades cometidas.

As estratégias para se burlar a legislação trabalhista não se concentram somente em pequenas empresas, como a que foi objeto da pesquisa de campo realizada para este trabalho. Atualmente, as grandes construtoras têm investido na regularização dos empreiteiros, os"gatos", através da ampliação da terceirização. Muitas vezes, elas incentivam seus próprios encarregados, mestres de obra, ou mesmo trabalhadores de ofício mais experientes, a registrarem uma microempresa de serviços específicos, que, no canteiro de obra, passa a ser chamada de empreiteira. Essas mini-empresas são, muitas vezes, montadas com o propósito de servir somente a uma construtora. Com isso, essa última se beneficia duplamente. Por um lado, ela burla a legislação e, por outro, garante a mesma qualidade em suas construções, pois consegue manter os mesmos funcionários já treinados e habituados com seus padrões construtivos, às vezes, por anos.

\section{A fiscalização}

Os acordos entre a empresa e os trabalhadores, no sentido de mascarar a real situação de clandestinidade, não se estendem a todos. Uma parte dos empregados no processo de construção, sobretudo os de curta permanência, não possui registro algum em carteira, fato curioso, uma vez que, devido à imprevisibilidade da chegada da fiscalização, as penalizações podem ser elevadas. Diante disso, surgem duas questões. Por que a empresa prefere correr os riscos das multas? E, por que os acordos que mascaram a clandestinidade não são estendidos a todos que estão em situação irregular?

As respostas a essas perguntas podem ser encontradas na forma como é feita a fiscalização por parte do Ministério do Trabalho, e na burocracia, que retarda a necessidade do efetivo pagamento das multas. O foco da fiscalização incide sobre os aspectos relativos à segurança dos operários, no canteiro, aos equipamentos de uso pes- 
soal e de proteção contra acidentes; aos aspectos relacionados ao bem-estar dos trabalhadores, tais como presença de refeitórios, de banheiros e lavatórios; e ainda sobre as formas dos contratos de trabalho, além de uma série de exigências previstas pelo código NR18. ${ }^{1}$

A presença da fiscalização nos canteiros de pequeno porte é rara. Como muitos dos profissionais permanecem pouco tempo na obra, as construtoras acabam "jogando" com a imprevisibilidade. Mesmo a atuação sindical, nesse caso, não parece ser suficiente, como explica o já citado presidente do Sindicato dos Trabalhadores da Construção Civil da RMBH:

Quando a gente tem uma denúncia, a gente encaminha pro Ministério do Trabalho. A gente pede fiscalização. Agora, infelizmente, também o Ministério do Trabalho é muito omisso, é um órgão que não funciona. Se, por exemplo, um empreiteiro pega uma obra de seis meses, sete, oito meses pra fazer, você costuma encaminhar um ofício solicitando fiscalização justamente por esse tipo de coisa: "Ó, os trabalhadores estão trabalhando a metro, por produção. Eles, não estão tendo um salário integral, conforme a regra da convenção coletiva”. Aí os caras vão lá, vocề manda um ofício e protocola lá. Aí, quando eles vão na obra, eles te ligam: "Ó, nós não estamos localizando a obra não!”. "Claro que você não vai localizar. [ela] Acabou!”.

As elevadas multas decorrentes da eventual autuação não parecem ser suficientes para que se formalizem os contratos. Como explica o engenheiro Neilor, proprietário da obra pesquisada:

Eles não vêm em toda obra não. Só mesmo se tiver alguma denúncia. Aqui eles vieram porque os vizinhos denunciaram, por causa do barulho, mas é raro. Tem quinze anos que eu construo aqui. Fiscal só apareceu em minhas obras três vezes. Mas quando eles vêm, eles chegam com o intuito de prejudicar. Não vai ajudar em nada. Não é orientar pra poder ajudar. Eles são muito arrogantes, muito, muito.

Além da possibilidade de o canteiro não ser fiscalizado durante todo o processo de construção, as multas, mesmo que sejam altas, são passíveis de recurso. Com a lentidão dos julga-

${ }^{1}$ Condições e Meio Ambiente de Trabalho na Indústria da Construção - Código de normas técnicas relativas à prevenção de acidentes de trabalho. Quinto capítulo da CLT. mentos, pode-se prorrogar por anos a efetivação de um pagamento. Algumas multas, não raro, ainda acabam sendo abonadas. Por fim, quando uma empresa tem de arcar com as multas, de fato o pagamento ocorre anos depois do término da obra, que utilizou dezenas de trabalhadores com contratos informais.

As construtoras se preocupam em bem orientar seus empregados a negar quaisquer ilegalidades, em uma eventual abordagem de fiscais. A empresa e os próprios empreiteiros tentam, de fato, transferir para os trabalhadores a responsabilidade de convencer os fiscais sobre a legalidade de sua situação, de modo a evitar ou minimizar as punições. As empresas, ou os empreiteiros, frente a uma eventual presença da fiscalização e dos interrogatórios, orientam os trabalhadores, em situação clandestina, a darem respostas que escamoteiem a verdade. Como explica Jorge, pedreiro de acabamento: "Se chegar aqui e me perguntar, eu falo: eu estou fazendo um teste aqui pra eles, não sei se eles vão me querer; é que eu comecei o trabalho hoje". Perguntado se teria sido orientado a responder assim, o trabalhador responde:

Aqui não, mas a gente sabe, né, das outras firmas em que a gente trabalhou. Todo mundo responde isso. Mas eles, às vezes, não caem nessas, porque eles perguntam: "Mas quem fez os outros acabamentos dos banheiros?". Eu falo que não sei, mas o encarregado diz que foi um dos pedreiros fichados. Mas eles costumam multar assim mesmo. É por isso que eles assinam a sua carteira e põem você "a metro". Isso não é certo. Todo mundo sabe que isso não é certo.

Esse relato demonstra, com eficácia, o que acontece com a maioria dos trabalhadores irregulares, no canteiro. Quando questionados pela fiscalização, respondem sempre algo semelhante, usando argumentos que possam minimizar a autuação da empresa. O trabalhador, então, acaba por proteger a empresa, negando informações sobre a verdadeira situação de seu contrato de trabalho, o que o coloca em um aparente paradoxo contra as leis que foram feitas para protegê-lo. 
Podemos pensar, hipoteticamente, em três elementos para justificar essa atitude: i) os trabalhadores de ofício, que possuem contratos informais, estão inseridos, há anos, em um mercado de trabalho que estabeleceu a informalidade, o que faz com que eles não tenham alternativa. Dentro das possibilidades oferecidas pelo setor, o trabalho por produtividade com um contrato informal é ainda a forma mais lucrativa, para eles; ii) em uma cidade pequena, em que os trabalhadores se conhecem e são conhecidos pelas construtoras, há um certo constrangimento, no momento de revelar à fiscalização os reais tipos de contrato. Há, ainda, o temor de recorrer ao Sindicato, pois, ao fazê-lo, os trabalhadores ficariam "marcados" no mercado de trabalho local, ou seja, não encontrariam nova colocação; iii) vive-se, nos canteiros, uma relação paternalista, que se estabelece entre os trabalhadores e o engenheiro, dono da construtora, visto como um "bom patrão", por emprestar dinheiro, quando os funcionários precisam desse tipo de ajuda, por permitir aos trabalhadores saírem mais cedo, por algum motivo, e por "aceitar" o fato de alguns deles até morarem no canteiro. Isso acaba por deixar os operários compromissados, vinculados pela amizade e pela cumplicidade sentidas em relação ao patrão e aos demais encarregados. O que se percebe é que é preciso que os trabalhadores compactuem com esse estado de coisas para se manterem na empresa, garantindo-se, de algum modo, em um mercado de trabalho marcado pela incerteza.

\section{FINALIZANDO}

Este artigo pretendeu expor dados de pesquisas de campo realizadas em canteiros de obras, no Brasil e na França. Os resultados parecem revelar, em alguns aspectos, situações, muito semelhantes, guardadas, obviamente, as especificidades que caracterizam cada país. A precarização do trabalho, decorrente da clandestinidade das contratações, e a informalidade parecem se consolidar como formas de regulação das relações trabalhistas, em um setor que sempre contou com um grande contingen- te de mão de obra migrante, de baixa escolaridade, em ambos os países.

A diferença quanto à precarização dos trabalhos, nos dois países, no âmbito da construção civil, reside, essencialmente, na forma das práticas ilegais. Como se pôde notar, na França, a precarização dos contratos se realiza, principalmente, pela intermediação das agências de temporários, através da utilização, em massa, dos imigrantes sem documentação legal. Apesar de assegurarem certos direitos trabalhistas, tais agências produzem a instabilidade do trabalhador em relação a seu ofício, pois garantem, para as empresas utilizadoras, a possibilidade de se desvencilharem do empregado a qualquer momento. A prestação transnacional de serviços, que vem se consolidando como uma estratégia para burlar a legislação francesa, nesse contexto, aponta para " esquemas bem organizados de fornecimento clandestino de mão de obra.

O surgimento das agências de temporários, na França, no início dos anos 1970, foi uma tentativa de o governo fornecer possibilidades de contratos alternativos. Flexibilizando a legislação, tinha-se em vista, claramente, minimizar a precariedade envolvida no trabalho informal. No entanto, ao menos no setor da construção civil, o efeito foi contrário. O que tentamos demonstrar é que as agências possuem inúmeras possibilidades de burlar a legislação, sobretudo através da reconfiguração dos contratos e da utilização maciça de imigrantes ilegais.

No caso brasileiro, a precarização se realiza diretamente pelas construtoras, ou através dos agenciadores ilegais de pequeno porte, os denominados "gatos". Esses últimos, em meio às circunstâncias precárias do setor da construção civil, conseguem viabilizar pequenos lucros, ao repassar serviços, por menores valores, a outros trabalhadores.

O que se pode pensar, a partir da experiência francesa, é que os debates, no Brasil, sobre a desregulamentação dos mercados e a flexibilização das relações de trabalho, como possíveis saídas para o desemprego e para o com- 
bate à informalidade, são questionáveis. Lembrando que a utilização das agências de temporários foi desenvolvida, no seu início, como forma de minimizar a informalidade e combater o desemprego, devemos reconhecer que elas servem, atualmente, como uma forma de legalizar a precarização, sobretudo, dos imigrantes clandestinos, para os quais os seus efeitos são ainda mais perversos.

Tanto no Brasil como na França, essa flexibilização das relações trabalhistas sempre foi grande. Também o empresariado, nos dois países, sempre dispôs de vantagens, tanto na contratação como na demissão de trabalhadores, sobretudo nas pequenas empresas construtoras, que tendem a utilizar meios informais de trabalho. Essa situação se reforça dentro de um quadro de competitividade crescente, em que o cumprimento da legislação surge como algo residual. Atualmente, em ambos os países e devido à fragilidade dos mecanismos de fiscalização, os empresários do setor, possuem inúmeras estratégias para burlar a legislação, seja ela mais flexível, como no caso da França, seja menos flexível, como no caso do Brasil.

Diferentemente do que ocorre na França, o setor da construção civil, no Brasil, ainda é muito atrativo para os trabalhadores de origem rural, que migram para os grandes centros urbanos, onde encontram, nas obras, seu primeiro emprego, exatamente como o fazem, na França, os imigrantes. É importante ressaltar que as grandes empresas brasileiras estão envolvidas em um movimento de racionalização do processo produtivo, em uma tentativa de reduzir as variabilidades típicas dos trabalhos nos canteiros. Os modelos de qualidade, já muito comuns em outros setores industriais, têm contribuído não apenas para a ampliação das exigências de qualidade, como também para cobrar dos trabalhadores um maior envolvimento com as empresas. Com isso, tem-se percebido uma redução dos contratos informais praticados diretamente pelas grandes empresas. A essa redução corresponde, entretanto, a transferência das ilegalidades para as empreiteiras terceirizadas, legalmente registradas. Preserva-se, então, e de for- ma crescente, a precarização dentro do que poderíamos chamar de "novas institucionalidades" (Lima, 2006) no mundo do trabalho, povoado, agora, por novos personagens, como estagiários, cooperativas, pessoas jurídicas, misturados aos antigos trabalhadores.

(Recebido para publicação em 06 de outubro de 2010) (Aceito em 27 de maio de 2011)

\section{REFERÊNCIAS}

CARNET, P. Entre contrôle et tolérance: précarisation des migrants dans l'agriculture d'Almeria. Etudes Rurales, Paris, n.182, p.201-218, jul./dez, 2008.

CASTEL, R. As metamorfoses da questão social: uma crônica do salário. Petrópolis: Vozes, 1998.

CHAUVIN, S.; JOUNIN. N. L'externalisation des illégalités: ethnographie des usages du travail "temporaire" à Paris et Chicago. In: WEBER, Florence.; BARBE, Noël. L'écomomie informelle: une jeu avec les règles. 2008. Disponível em: www.cmh.ens.fr/ hopfichiers/fichierspub/Chauvin-Jouninexternalisation2008.pdf. Acesso em: 15 abr. 2007.

COCKELL, Fernanda. Da enxada à colher de pedreiro: trajetórias de vulnerabilidade social na construção civil. 2008. 206f. Tese (Doutorado em Engenharia de Produção) - Programa de Pós-Graduação em Engenharia de Produção da Universidade Federal de São Carlos, SP. 2008.

DRUCK, Graça; THÉBAUD-MONY, A. Terceirização: a erosão dos direitos dos trabalhadores na França e no Brasil. In: ; FRANCO, T. (Org.) Perda da razão social do trabaIho. São Paulo: Boitempo, 2007. p.23-58.

GLAYMANN, Dominique. L'interim. Paris: La Découverte, 2007. 121 p.

JOUNIN, Nicolas. Chantier interdit au public. Paris: La Découverte, 2008. 275 p.

Des sans-papiers locaux à la sous-traitance internationale: trajectoire d'un métier du bâtiment: le ferraillage. 2008.19 p. Mimeo.

Loyautés incertaines: les travailleurs du bâtiment entre discrimination et précarité. 2006. 619 f. Thèse (Doctorat Sciences Sociales) - Université Paris VII. Paris, 2006

LAE, Jean F. Travailler au noir. Paris: Èditions Métailie,1989. $228 \mathrm{p}$.

LAUTIER, B.; PEREIRA, J. Representações sociais e construção do mercado de trabalho: empregadas domésticas e operários da construção civil na América Latina. Caderno CRH: Centro de Recursos Humanos, Salvador, n.21. p.125151, jul./dez, 1994.

LIMA. J. Redes sociais e mercado de trabalho: entre o formal e o informal. Política e Trabalho, João Pessoa, n.24, p.7398, abr., 2006.

MORICE, A. Os peões da construção civil em João Pessoa. Espaço e Debate, São Paulo, n.36, p.35-46, 1992.

PORTES, A.; CASTELLS, M.; BENTON, L. A. The informal economy: studies in advanced and less developed countries. Baltimore: The Johns Hopkins University Press, 1989. 351 p. 
PERALVA, A. Globalização, migrações transnacionais e The informal economy: studies in advanced and less identidades nacionais. São Paulo: Instituto Fernando developed countries. Baltimore: The Johns Hopkins Henrique Cardoso, 2007. 46 p. Mimeo.

University Press, 1989. p.71-90.

REA, A. Politiques d'immigration: criminalisation ou TOMASI. A. A construção social da qualificação dos tratolérance? La Pensée de Midi, Paris, n.10, p.111-125, 2003. $\begin{aligned} & \text { balhadores da construção civil de Belo Horizonte: um es- } \\ & \text { tudo sobre os mestres-de-obras. Belo Horizonte: CNPq, }\end{aligned}$ SASSEN-KOOB, Saskia. New York city's informal economy. 1999.250 p. Relatório.

In: PORTES, A.; CASTELLS, M.; BENTON, L. A. (Org) 


\section{SUBCONTRACTING AND INFORMALITY IN CIVIL CONSTRUCTION, IN BRAZIL AND FRANCE}

\author{
Luciano Rodrigues Costa
}

This paper presents a comparative analysis of the labor market of the construction industry in Brazil and France, in a context of flexibility. This text, being the result of field research on construction sites in these two countries, discusses specifics of the informal labor contracts in the sector, which have produced a transfer of illegalities from large to small businesses. In the French case, through temporary agencies. In Brazil, through small businesses underground, called "kittens." The perception of workers against such illegalities and their strategies to stay on the market are emphasized. In the French case, the work of illegal or semi-legal immigrants, made possible by temporary agencies. In Brazil, it is clear that the industry has always been organized based on informality and seeks, gradually, to retain workers, even though informal work remains predominant.

Keywords: informality, subcontracting, civil construction, labor, precariousness.

\section{SOUS-TRAITANCE ET INFORMALITÉ DANS LA CONSTRUCTION CIVILE, AU BRÉSIL ET EN FRANCE}

\author{
Luciano Rodrigues Costa
}

Cet article présente une analyse comparative du marché du travail dans la Construction Civile au Brésil et en France, dans un contexte de flexibilité. Fruit des recherches de terrain effectuées sur des chantiers de construction dans ces deux pays, ce texte aborde les spécificités des contrats de travail informels dans le secteur qui entrainent un transfert d'illégalités des grandes aux petites entreprises. Dans le cas français, ceci se fait par le biais des agences d'intérim, au Brésil, par le biais des petites entreprises clandestines, appelées "gatas". On y souligne la perception de ces illégalités par les travailleurs et les stratégies utilisées pour rester sur le marché. Dans le cas français, l'accent est mis sur le travail des immigrés clandestins ou porteurs de titres de séjour précaires, rendus possibles par les agences de travail intérimaire. $\mathrm{Au}$ Brésil on peut se rendre compte que le secteur a toujours été organisé sur la base de l'informel mais cherche progressivement à fidéliser les ouvriers, même si le travail informel reste prédominant.

MотS-CLÉs: informalité, sous-traitance, construction civile, travail, précarité.

Luciano Rodrigues Costa - Doutor em Ciências Sociais, com Estágio Doutoral na Université de Toulouse le Mirail UTM e na École des Hautes Études en Sciences Sociales (EHESS). Professor Substituto no Departamento de Ciências Sociais na Universidade Federal de Viçosa (UFV). Participa do Acordo Capes-Cofecub (Brasil (USP) França UTM) “Trajetórias, circuitos e redes urbanas, nacionais e transnacionais e o seu impacto sobre a arquitetura institucional democrática”. Tem experiência na área de Sociologia do Trabalho, Teoria Sociológica, Sociologia das Organizações e Metodologia Científica. Publicou, entre outros textos, o artigo: $O$ canteiro de obras é escola? Formação e qualificação profissional na Construção Civil. Teoria \& Sociedade (UFMG) v. 17.2, p. 94-117, 2009. 